Reviews in Digital Humanities •

\title{
Review: Sonic Histories of Cork City
}

James ManselI ${ }^{1}$

${ }^{1}$ University of Nottingham

Published on: Sep 13, 2021

License: Creative Commons Attribution 4.0 International License (CC-BY 4.0). 


\section{Project}

Sonic Histories of Cork City

\section{Project Directors}

Jillian Rogers, Indiana University

Elaine Harrington, University College Cork

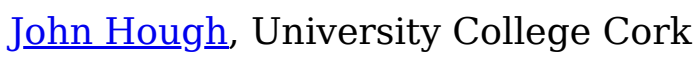

\section{Project URL}

https://shoccproject.wordpress.com/

\section{Project Reviewer}

James Mansell, University of Nottingham

\section{Project Overview}

\section{Jillian Rogers, Elaine Harrington, and John Hough}

In April 2018, the Sonic Histories of Cork City (SHOCC) Project was launched as a dynamic public arts project exploring relationships between sound, space, and history. By using archival and historical sources, the SHOCC Project investigates what spaces in Cork City might have sounded like at various moments in the city's rich historical past. The project gives residents of and visitors to Cork opportunities to engage creatively with the city's histories through soundscapes and narratives in a digital, online format. In addition, the SHOCC Project has developed an online tool to enable Cork's residents and visitors to contribute to the city's sonic history. By engaging Cork City's public in the sonic histories of the city, the SHOCC Project aims not only to teach people about Cork City's fascinating past and present, but also to encourage people to think critically about the spaces in which they live and consider how social, political, environmental, and artistic factors have contributed to how Cork City sounded in the past and might sound in the future.

Using archival and historical sources, interdisciplinary project leaders musicologist Jillian Rogers, librarian Elaine Harrington, and sound designer John Hough ask questions about how social, environmental, economic, political, and historical factorsincluding the development of transport, globalization, changes in building materials, and the Irish War of Independence-may have altered the city and its soundscapes. The SHOCC Project was formed in the "lab" of MU6031: Sound Studies \& Musicology, 
a postgraduate course taught by Rogers in University College Cork's (UCC) Department of Music (2017-2019). From the first year of MU6031, it was clear that a long-term research project would be useful for investigating Cork's historical and contemporary soundscapes, with each year's cohort of MA students contributing to the research project. Students enrolled in this MA course-which began to be cross-listed with UCC's Digital Humanities MA program in 2018-contributed soundscapes and narratives to the project, resulting in a fascinating set of historically-focused, soundbased projects.

Although the educational component of the SHOCC Project has been paused due to Rogers's move to the U.S., the team has continued to present the project to new audiences while considering the shape that the now cross-continental project will take. First and foremost, the team aims to complete aspects of the project that were always intended but put on hold due to Rogers's move, financial considerations, and the COVID-19 pandemic. For instance, the team plans to turn Cork City into a "walking sonic museum" by posting QR codes that allow Cork's residents and visitors to access soundscapes and narratives, enabling people to create their own historically-informed soundwalks. Moreover, the team will continue collecting sounds of present-day Corkincluding recorded oral histories-for use by future researchers.

Looking to the future, the SHOCC team also sees Rogers's move to the U.S. as an opportunity to expand this sound-focused public history project beyond Cork City. First, the SHOCC Project plans to extend its current focus on historically-informed soundscapes and narratives, personally-curated soundwalks, and the creation of repositories of everyday sonic experiences to a variety of other locations-beginning with Indiana, where Rogers is located, but hopefully expanding beyond Indiana to other locales in Europe and the Americas by partnering with other global sound studies scholars and practitioners. In addition, the team wants to begin exploring diaspora through the lens of sound, asking questions about how diasporic experience intertwines with sensory experience in life-shaping ways. Here, too, oral histories will be important, as will the combination of archival and sound-recording work that is central to the SHOCC Project.

\section{Project Review}

\section{James Mansell}


Engaging with history via sound can help us to understand the lived, felt experiences of people from the past. Sonic Histories of Cork City (SHOCC) is a teaching and public engagement project led by musicologist Jillian Rogers, special collections librarian Elaine Harrington, and sound designer John Hough. The project began as an innovative audio production activity in a sound studies module offered in the Music Department at University College Cork. Students were invited to recreate "soundscapes" from Cork's past by searching for clues in written and visual sources about how particular streets, buildings, and industries might have sounded. This is more of an imaginative exercise than an archeo-acoustic one, with students borrowing sound effects from websites such as freesound.org and from Apple's Logic Pro X digital audio workstation, as well as making their own field recordings in present-day Cork. For example, by explicitly imagining the heard world of librarian D. Donnelly, the SHOCC 1882 Library soundscape acknowledges the power that lies in listening with past listeners. Current research in sound studies calls for decentering of and multiplication of the listening perspective in auditory research, and projects like SHOCC are perfectly placed to help us understand not just what Cork sounded like but what it means to listen to it in different times and places and from different perspectives.

There is lovely attention to detail in some of these soundscapes. For example, Shauna Caffrey recreates the sounds of the Singer Sewing Machine Centre in the 1870s and the 1960s using recordings of an 1873 vibrating shuttle bobbin sewing machine and a later electronic version. The project team also contributed by reimagining the sounds of Queen's College Cork Library in 1882. The focus in these soundscapes is historicallyinformed audio production rather than historical acoustemology-hearing the footsteps in the recordings left me wondering about the acoustic properties of 19th-century footwear-but that is not a bad thing. As a public history project, SHOCC intends to spark imagination about the sonic past rather than rigorously excavate it. In a second strand of activity, the project invites the public to imagine what the historian of the future might want to hear by uploading significant sounds of contemporary Cork to an online sound map.

SHOCC is presented using WordPress with embedded Soundcloud audio streaming for the soundscapes and JotForm/Google Maps for the sound map. Unlike many online city sound map projects, SHOCC's user-generated audio will be professionally archived by the project team. It remains to be seen whether this collecting and digital preservation work-or an alternative ambition articulated by the project team to "museumify" Cork with sound installations, soundwalks, and VR experiences-will take centre stage as 
SHOCC develops in the future. Either would be valuable and interesting contributions to the growing field of digital sound studies.

Whether or not the "soundscape" approach is appropriate is currently subject to debate, with some calling into question its tendency to universalize and normalize "the listener." Alternative approaches such as Dylan Robinson's "guest listening" methodology might prove more suited to a progressive public sound history. Regardless, projects like SHOCC will play an important role in testing new ways of delivering sound-based pedagogy and public history.

Works Cited

Robinson, Dylan. Hungry Listening: Resonant Theory for Indigenous Sound Studies. University of Minnesota Press, 2020. 